\title{
Shank3 Is Part of a Zinc-Sensitive Signaling System That Regulates Excitatory Synaptic Strength
}

\author{
Magali H. Arons, ${ }^{1 \star}$-Kevin Lee, ${ }^{2 \star}$ Charlotte J. Thynne, ${ }^{2}$ CSally A. Kim, ${ }^{1}$ Claudia Schob,${ }^{3}$ Stefan Kindler, ${ }^{3}$ \\ [DJohanna M. Montgomery, ${ }^{2 \star}$ and Craig C. Garner ${ }^{1,4 *}$ \\ ${ }^{1}$ Department of Psychiatry and Behavioral Sciences, Stanford University, Stanford, California 94305, 2Department of Physiology, University of Auckland, \\ Auckland 92019, New Zealand, ${ }^{3}$ Institute for Human Genetics, University Medical Center Hamburg-Eppendorf, 20246 Hamburg, Germany, and ${ }^{4}$ German \\ Centers for Neurodegenerative Disorders, Charité-Universitätsmedizin Berlin, 10117 Berlin, Germany
}

Shank3 is a multidomain scaffold protein localized to the postsynaptic density of excitatory synapses. Functional studies in vivo and in vitro support the concept that Shank3 is critical for synaptic plasticity and the trans-synaptic coupling between the reliability of presynaptic neurotransmitter release and postsynaptic responsiveness. However, how Shank3 regulates synaptic strength remains unclear. The C terminus of Shank3 contains a sterile alpha motif (SAM) domain that is essential for its postsynaptic localization and also binds zinc, thus raising the possibility that changing zinc levels modulate Shank3 function in dendritic spines. In support of this hypothesis, we find that zinc is a potent regulator of Shank3 activation and dynamics in rat hippocampal neurons. Moreover, we show that zinc modulation of synaptic transmission is Shank3 dependent. Interestingly, an autism spectrum disorder (ASD)-associated variant of Shank3 $\left(\right.$ Shank $3^{\mathrm{R} 87 \mathrm{C}}$ ) retains its zinc sensitivity and supports zinc-dependent activation of AMPAR-mediated synaptic transmission. However, elevated zinc was unable to rescue defects in trans-synaptic signaling caused by the R87C mutation, implying that trans-synaptic increases in neurotransmitter release are not necessary for the postsynaptic effects of zinc. Together, these data suggest that Shank3 is a key component of a zinc-sensitive signaling system, regulating synaptic strength that may be impaired in ASD.

Key words: hippocampus; postsynaptic density; Shank3; zinc

\section{Significance Statement}

Shank3 is a postsynaptic protein associated with neurodevelopmental disorders such as autism and schizophrenia. In this study, we show that Shank3 is a key component of a zinc-sensitive signaling system that regulates excitatory synaptic transmission. Intriguingly, an autism-associated mutation in Shank3 partially impairs this signaling system. Therefore, perturbation of zinc homeostasis may impair, not only synaptic functionality and plasticity, but also may lead to cognitive and behavioral abnormalities seen in patients with psychiatric disorders.

\section{Introduction}

The Shank family of proteins (Shank1/ProSAP3, Shank2/ProSAP1, and Shank3/ProSAP2) are highly enriched within the

Received Jan. 8, 2016; revised July 6, 2016; accepted July 8, 2016.

Author contributions: J.M.M. and C.C.G. designed research; M.H.A., K.L., C.J.T., S.A.K., C.S., and S.K. performed research; M.H.A., K.L., J.M.M., and C.C.G. analyzed data; J.M.M. and C.C.G. wrote the paper.

This work was funded by the Marsden Fund (Royal Society of New Zealand), the German Academic Exchange (DAAD Research Scholarship to J.M.M.), the Neurological Foundation of New Zealand (J.M.M.), the National Institutes of Health (Grant MH100717), United States/Israel Binational Science Foundation (2007425), Phelan McDermid Syndrome Foundation, NeuroCure, the Federal Government of Germany (Grant SFB665) and the German Center for Neurodegenerative Disorders (C.C.G.). We thank members of the Montgomery and Garner laboratories for helpful discussion and Sergio Leal-Ortiz and Noam Ziv for assistance with FRAP analysis.

The authors declare no competing financial interests.

*M.H.A. and K.L. contributed equally to this work. J.M.M. and C.C.G. share senior co-authorship.

Correspondence should be addressed to either of the following: Craig C. Garner, DZNE-Berlin c/o CharitéUniversitätsmedizin Berlin, Virchowweg 6, 10117 Berlin, Germany, E-mail: craig-curtis.garner@dzne.de; or Johanna M. Montgomery, Department of Physiology and Centre for Brain Research, University of Auckland, Private Bag 92019, New Zealand. E-mail: jm.montgomery@auckland.ac.nz. postsynaptic density (PSD) of excitatory synapses in the hippocampus and cortex (Kreienkamp, 2008). Shank proteins exhibit differential temporal expression patterns, with Shank2 expression occurring early, followed by Shank3 and then Shank1 (Grabrucker et al., 2011b). They are considered central regulators of postsynaptic function, interacting with a large number of postsynaptic molecules including glutamate receptors, structural proteins, and the actin cytoskeleton (Boeckers et al., 2002; Kreienkamp, 2008). Shank3 also interacts with the C-terminal tails of Neuroligin 1 and 3 (Meyer et al., 2004) and thus couples changes in postsynaptic reception with presynaptic neurotransmitter release via the trans-synaptic Neurexin/Neuroligin complex (Arons et al., 2012). Both knock-down of endogenous Shank3 and overexpression of autism spectrum disorder (ASD)- 
associated Shank3 variants interfere with trans-synaptic signaling, indicating that presynaptic and postsynaptic coupling are likely targeted by ASD mutations (Kumar and Christian, 2009; Miles, 2011; Arons et al., 2012). Shank3-deficient mice show deficits in glutamatergic excitatory synaptic transmission, decreased LTP expression, and altered social interaction and anxietyrelated behaviors (Bozdagi et al., 2010; Wang et al., 2011; Kouser et al., 2013; Duffney et al., 2015; Lee et al., 2015; Speed et al., 2015). Together, these data indicate that Shank3 is critical for long lasting forms of synaptic plasticity that underpin behavior.

The C-terminal sterile alpha motif (SAM) domain in Shank3 (Boeckers et al., 2005) binds zinc and this binding affects Shank3's oligomerization state in vitro (Baron et al., 2006). In primary neurons, modulation of zinc levels alters the thickness of the PSD and the synaptic localization of Shank3 and other synaptic proteins such as Homer1, but only in young neurons, which express higher levels of zinc-sensitive Shanks (Shank2 and Shank3; Grabrucker et al., 2011b). The later expression of Shank1, the zinc-insensitive Shank, decreases the zinc responsiveness of synaptic proteins in more mature neurons (Grabrucker et al., 2011b). Intriguingly, the overexpression of Shank1 can drive young neurons to become zinc insensitive, with no loss of synapses or effect on synaptic protein expression occurring with zinc chelation (Grabrucker et al., 2011b).

At synapses, zinc is stored in glutamatergic synaptic vesicles and coreleased with glutamate (Assaf and Chung, 1984; Howell et al., 1984; Westbrook and Mayer, 1987; Mayer and Vyklicky, 1989; Smart et al., 1994). Vesicular zinc release is required for the induction of presynaptic mossy fiber LTP by changing $\operatorname{Pr}$ (Lu et al., 2000; Li et al., 2001; Pan et al., 2011) and has also been shown to enhance postsynaptic LTP in area CA1 of the hippocampus in a concentration-dependent manner by subunit-specific modulation of the NMDA and P2X receptors (Izumi et al., 2006; Takeda et al., 2010; Lorca et al., 2011; Takeda et al., 2012). Zinc enters the postsynaptic neuron via different channels, including calciumpermeable AMPA receptors, NMDA receptors, voltage-gated calcium channels, and TRPM7 channels (Manzerra et al., 2001; Kim et al., 2002; Huang et al., 2008; Paoletti et al., 2009; Inoue et al., 2010; Watt et al., 2013), where it is highly enriched within dendritic spines (Li et al., 2001; Grabrucker et al., 2011b) and modulates synaptic transmission and plasticity (Mayer and Vyklicky, 1989; Izumi et al., 2006; Takeda et al., 2010; Lorca et al., 2011; Pan et al., 2011) through mechanisms that are poorly understood. Once in the spine, buffers such as metallothionein III likely facilitate the sequestration of free zinc (Ebadi et al., 1990; Masters et al., 1994; Grabrucker et al., 2014).

Here, we investigated whether zinc-dependent regulation of synaptic function involves Shank3. In particular, we investigated whether zinc modulates the real-time dynamics and transsynaptic signaling of Shank3. We also studied the role of Shank3 in zinc-dependent modulation of synaptic transmission. Our studies reveal that Shank3 dynamics and activation are indeed regulated by zinc. Moreover, we find that Shank3 is essential for zinc-dependent modulation of AMPAR-mediated synaptic transmission. Intriguingly, an ASD-associated Shank3 variant $\left(\right.$ Shank $3^{\mathrm{R} 87 \mathrm{C}}$ ) that impairs synaptic signaling (Arons et al., 2012) remains responsive to zinc and, while still supporting zincdependent increases in synaptic transmission, it fails to mediate trans-synaptic signals that modulate the reliability of presynaptic neurotransmitter release. These data support the concept that Shank3 is a crucial regulator of zinc-dependent signaling at excitatory synapses.

\section{Materials and Methods}

Neuronal cultures. Primary dissociated hippocampal neuron cultures were prepared from embryonic day 18 (E18) rats of either sex as described previously (Goslin et al., 1988). All animal experiments were performed in compliance with the guidelines for the welfare of experimental animals issued by the National Institutes of Health. All experiments were conducted in strict compliance with Administrative Panel on Laboratory Animal (APLAC)-approved animal protocols from Stanford University (protocol \#14607) and The University of Auckland.

Expression constructs and transfection. To examine zinc-dependent effects on Shank3 synaptic signaling, Shank3 activation, and synapse function specifically, hippocampal neurons were transfected at $9 \mathrm{~d}$ in vitro (DIV9) with wild-type-Shank3 (WT-Shank3), a Shank3 ASD point mutant (Shank $3^{\mathrm{R} 87 \mathrm{C}}$ ), or shRNA-Shank3 using Lipofectamine 2000 (Thermo Fisher Scientific) or calcium phosphate precipitation (Waites et al., 2009). cDNA fragments encoding full-length WT-Shank3 and Shank3 ${ }^{\text {R87C }}$ from rat were cloned into pDEST53 (Thermo Fisher Scientific) and pEGFP C1 (Clontech) vectors, respectively (Arons et al., 2012). An shRNA specifically targeting rat Shank3 mRNAs was expressed using pZOff (Leal-Ortiz et al., 2008; Arons et al., 2012).

Immunostaining. At DIV14, cells were placed in one of four Tyrode's solution conditions for 30 min: normal Tyrode's solution, Tyrode's solution containing zinc as $10 \mu \mathrm{M} \mathrm{ZnCl}_{2}$ or $30 \mu \mathrm{M} \mathrm{ZnCl}_{2}$, or Tyrode's solution with zinc depletion (10 $\mu \mathrm{M}$ TPEN). Neurons were fixed in $4 \%$ paraformaldehyde with sucrose, followed by ice-cold methanol, for an additional $15 \mathrm{~min}$. Cells were washed, permeabilized, and incubated in blocking solution (2\% BSA, $2 \%$ glycine, $0.2 \%$ gelatin in $50 \mathrm{mM} \mathrm{NH}_{4} \mathrm{Cl}$ ), followed by primary antibody incubation (Homer1, Synaptic Systems; VGLUT1, NeuroMab) for $1 \mathrm{~h}$ at room temperature (RT). Cells were washed in PBS, incubated for $1 \mathrm{~h}$ at RT with secondary antibodies, washed again, and mounted on slides (Vector Laboratories).

Synaptic measurements, analysis, and statistics. Images of synapses from immunostained hippocampal neurons were taken on a spinning disk confocal microscope (Zeiss) with MetaMorph image acquisition software as described previously (Arons et al., 2012). Puncta-by-puncta analysis was performed using Openview, which individually boxes puncta and measures puncta intensity values in each of the channels. Puncta intensity values in transfected neurons were normalized to values in untransfected neurons and the data plotted as ratios of transfected versus untransfected cells, as in our previous work (Arons et al., 2012). Because zinc does not induce changes in synaptic protein levels in untransfected mature neurons that express Shank1 (Grabrucker et al., 2011b), this ratio analysis reveals the absolute change in Shank3transfected neurons. The normalization of fluorescent intensities between transfected and nontransfected cells on the same coverslip also reduces variability between experimental preparations and provides a direct measure of differences in expression levels under identical conditions. Statistical analysis was performed using Microsoft Excel and data were tested for significance using two-tailed Student's $t$ test and ANOVA. $p$-values $<0.05$ were considered significant.

Fluorescence recovery after photobleaching (FRAP) and live imaging. All live imaging experiments were performed on a custom-built (by C.C.G.) scanning confocal microscope (Leal-Ortiz et al., 2008). FRAP was performed as described previously (Tsuriel et al., 2006; Waites et al., 2009). Neurons were live mounted in a perfusion system with Tyrode's medium containing baseline zinc (normal Tyrode's), added zinc (10 or $30 \mu \mathrm{M}$ $\mathrm{ZnCl}_{2}$ ), or zinc depletion (10 $\mu \mathrm{M}$ TPEN). FRAP was performed $20 \mathrm{~min}$ after the addition of zinc or TPEN. Three baseline images were acquired before FRAP was performed, selecting five to six puncta and bleaching them to $\sim 10-20 \%$ of their initial fluorescence value by multiple scanning passes (15-20) of a high-intensity laser beam (488 nm wavelength). The recovery of fluorescence at the bleached puncta was imaged for 45 min, every $30 \mathrm{~s}$ for the first $7.5 \mathrm{~min}$ and then every $2.5 \mathrm{~min}$ thereafter.

For each time point $t$, FRAP intensity values of all puncta were expressed relative to baseline fluorescence before bleaching $\left(I_{\text {pre }}\right)$. To control for the continuous photobleaching during image acquisition, the intensity of bleached puncta $\left(I_{t} / I_{\text {pre }}\right)$ was normalized against that of non- 
bleached puncta $\left(I_{\mathrm{nb}, \mathrm{t}} / I_{\mathrm{nb}, \mathrm{pre}}\right)$ at the same time point and in the same field of view according to the following equation:

$$
F_{t}=\frac{I_{t} \cdot I_{n b, p r e}}{I_{p r e} \cdot I_{n b, t}}
$$

To allow us to calculate the means of the recovery traces for each condition, the FRAP data were further normalized to the first value after photobleaching ( $t=0$, set to zero) as follows:

$$
F_{\text {norm }}=\frac{F_{t}-F_{0}}{F_{p r e}-F_{0}}
$$

where $F_{\text {norm }}$ is the normalized relative fluorescent intensity, $F_{\mathrm{t}}$ the intensity at time $t, F_{0}$ at time $t=0$, and $F_{\text {pre }}=1$ the intensity before photobleaching. Curves were fitted to the mean experimental data according to the following equation, as described previously (Tsuriel et al., 2006):

$$
f(t)=a \cdot\left(1-e^{-\frac{t}{\tau_{1}}}\right)+(1 \cdot a)\left(1-e^{-\frac{t}{\tau_{2}}}\right)
$$

where $\tau_{1}$ and $\tau_{2}$ are two recovery time constants and $a$ and $(1-a)$ are the relative fraction of fluorescence in the two components. The theoretical parameters $a, \tau_{1}$, and $\tau_{2}$ were extracted through minimizing the sum of squared residuals using a macro written in Excel (by Noam Ziv).

Whole-cell recordings. Paired whole-cell patch-clamp recordings were performed from cultured hippocampal neurons as described previously (Waites et al., 2009; Li et al., 2011; Arons et al., 2012). Briefly, neurons were perfused at room temperature with artificial CSF (ACSF) containing the following (in mM): $119 \mathrm{NaCl}, 2.5 \mathrm{KCl}, 1.3 \mathrm{MgSO}_{4}, 2.5 \mathrm{CaCl}_{2}, 1$ $\mathrm{Na}_{2} \mathrm{HPO}_{4}, 26.2 \mathrm{NaHCO}_{3}$, and 11 glucose. For paired recordings, presynaptic neurons were held in current clamp and induced to fire action potentials by brief injection $(20 \mathrm{~ms})$ of depolarizing current. Postsynaptic neurons were held in voltage-clamp mode at $-65 \mathrm{mV}$ (Multiclamp; Axon). Internal solution consisted of the following (in mM): 120 potassium gluconate, $40 \mathrm{HEPES}, 5 \mathrm{MgCl}_{2}, 0.3 \mathrm{NaGTP}, 2 \mathrm{NaATP}$, and $5 \mathrm{QX} 314$ (postsynaptic cell only), pH 7.2. $\mathrm{ZnCl}_{2}(10 \mu \mathrm{M})$ or TPEN (10 $\mu \mathrm{M}$ ) were bath applied in ACSF to cultured neurons. No changes in cell health, morphology, or cell membrane integrity were detected electrophysiologically by bath application of $\mathrm{ZnCl}_{2}$ or TPEN. Series resistance (Rs) was monitored throughout the duration of all recordings and data were excluded if $R$ s increased $>20 \%$.

Online data acquisition and offline analysis was performed with pClamp (Clampex version 9.2). Failures rates of synaptic transmission were calculated as the percentage of trials throughout the duration of each paired recording in which no postsynaptic current was identified within $10 \mathrm{~ms}$ of the presynaptic action potential peak; that is, it was indistinguishable from baseline, as described in our previous studies (Montgomery et al., 2001; Arons et al., 2012). Due to the inherent variability in AMPAR EPSC amplitude between pairs of neurons (Pavlidis and Madison, 1999; Pavlidis et al., 2000; Montgomery et al., 2001; Waites et al., 2009; Li et al., 2011), AMPAR EPSC amplitudes before, during, and after zinc/TPEN application were normalized to baseline amplitude for each paired recording. Statistical significance was determined using two-tailed Student's $t$ test and ANOVA, with the level of significance set at $p<0.05$.

\section{Results}

\section{Shank3 synaptic signaling is zinc sensitive}

Shank3 plays a major role at excitatory synapses, where it has been shown to increase Homer levels and AMPA receptormediated postsynaptic responses and also to alter presynaptic VGluT1 levels and transmitter release probability via a transsynaptic signaling role (Arons et al., 2012). To assess the contribution of wild-type and ASD-mutant Shank3 to zinc-sensitive signaling at excitatory synapses specifically, we overexpressed Shank3 variants to create synapses with a higher percentage of Shank3 compared with Shank1 or Shank2. We applied physiologically relevant levels of zinc $(10-30 \mu \mathrm{M}$; note that $>100 \mu \mathrm{M}$ zinc concentrations are toxic to neurons; Sensi et al., 2011) and examined the activation and dynamic properties of Shank3 within dendritic spines. As a measure of Shank3 activation, we first used a trans-synaptic signaling assay that monitors changes in the levels of presynaptic and postsynaptic proteins at Shank3containing excitatory synapses (Arons et al., 2012; Fig. 1A-C). Quantifying the synaptic levels of VGLUT1 and Homer 1b at synapses with control (untransfected) or elevated levels of Shank3 (EGFP-Shank3 transfected) revealed an $\sim 160 \%$ increase in both VGLUT1 and Homer1b at EGFP-Shank3-containing synapses (Fig. $1 A, B$ ), supporting the hypothesis that Shank3 mediates trans-synaptic changes in synaptic protein levels (Arons et al., 2012).

To assess for a possible role for zinc in Shank3-mediated transsynaptic signaling, neuronal cultures expressing EGFP-Shank3 were exposed to exogenous zinc (10 or $30 \mu \mathrm{M} \mathrm{ZnCl} \mathrm{Zn}_{2}$ ) or TPEN $(10 \mu \mathrm{M})$, a cell-permeant zinc chelator, for $20 \mathrm{~min}$. Elevating extracellular zinc from $0.67 \mu \mathrm{M}$ (present in our Neurobasal medium) to 10 or $30 \mu \mathrm{M}$ maintained, but did not further increase, the Shank3-induced enhancement of both VGLUT1 and Homer1b at EGFP-Shank3 positive synapses. However, zinc chelation with TPEN significantly decreased the levels of both proteins compared with VGLUT1 and Homer1b levels in elevated zinc $(p<0.001$; Fig. $1 A, B)$. Moreover, VGLUT1 was also significantly reduced compared with baseline levels. These data show that changes in zinc levels can alter the ability of Shank3 to increase presynaptic and postsynaptic proteins, supporting the hypothesis that Shank3 synaptic signaling is zinc sensitive.

This hypothesis was tested directly by transfecting hippocampal neurons with a short-hairpin RNA (shRNA) that eliminates the expression of Shank3 selectively (sh-Shank3; Arons et al., 2012). As reported previously, knock-down of Shank3 had no effect on the levels of either VGLUT1 or Homer1b in untreated cells (Fig. 1B; Arons et al., 2012). In the absence of Shank3, $10 \mu \mathrm{M}$ TPEN did not affect the synaptic levels of these proteins. The absence of a response was not surprising because these synapses lacked zinc-responsive Shank3 but still expressed zinc-insensitive Shank1 (Grabrucker et al., 2011b). However, the addition of the higher zinc concentration $(30 \mu \mathrm{M})$ caused a decrease in VGLUT1 and Homer1b in Shank3-depleted versus Shank3-untransfected cells (Fig. 1B). In the absence of Shank3, we hypothesize that other synaptic proteins that respond to higher zinc concentrations may contribute to the regulation of VGluT and Homer levels (e.g., Shank2). Alternatively, our data suggest that higher zinc levels normally activate Shank3 and maintain synaptic protein levels and, in the absence of Shank3, high zinc is not able to maintain synaptic protein expression at normal levels.

Because control (untransfected) neurons express both zincresponsive (Shank2 and Shank3) and zinc-unresponsive (Shank1) proteins, we also compared directly zinc-induced changes in VGLUT/Homer1b in neurons with Shank3 gain of function with Shank3 loss of function (Fig. 1C). A normalized ratio of VGLUT1 and Homer1b in EGFP-Shank3-overexpressing neurons to neurons expressing sh-Shank3 was therefore calculated for each of the treatment conditions (Fig. 1C). This analysis indicates that most of the increase in trans-synaptic signaling caused by the overexpression of EGFP-Shank3 is regulated by zinc.

\section{Zinc-dependent regulation of excitatory synaptic transmission}

To determine whether the above zinc-induced changes in Shank3 synaptic signaling also induce functional changes in excitatory synaptic transmission, we performed paired whole-cell record- 

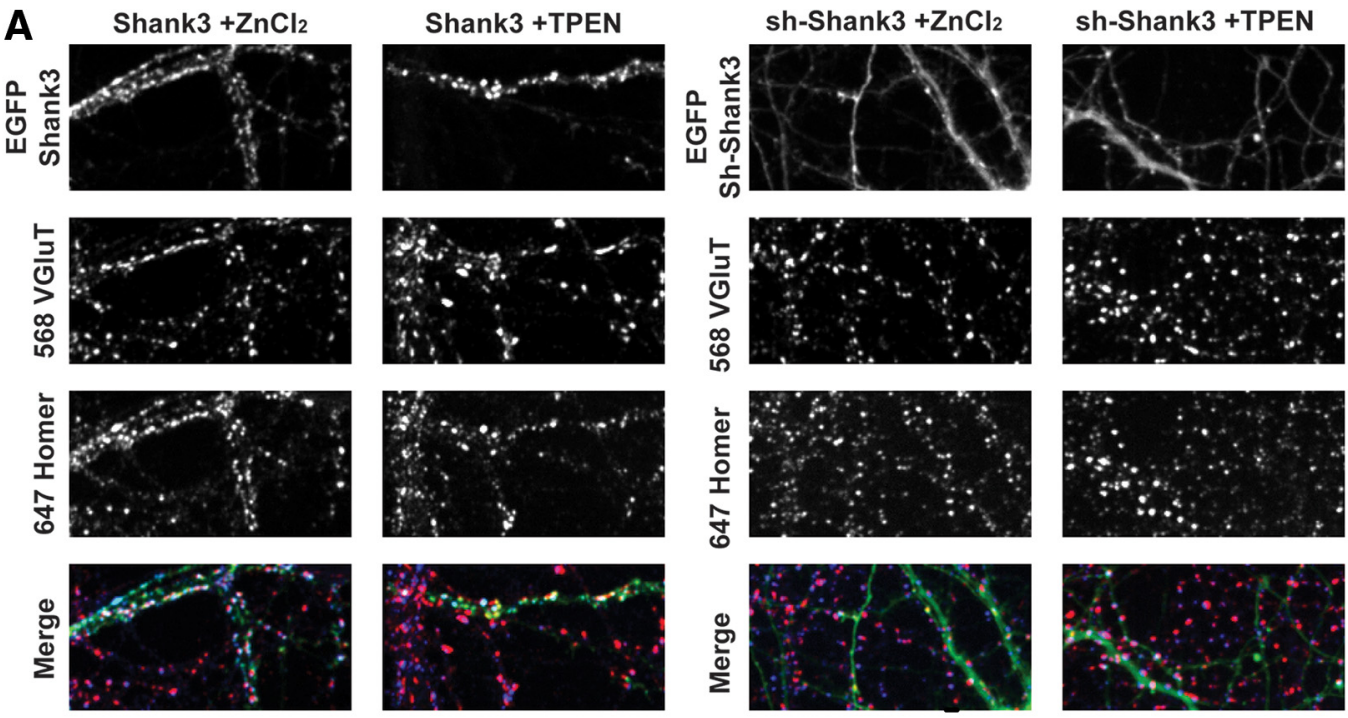

\section{B}

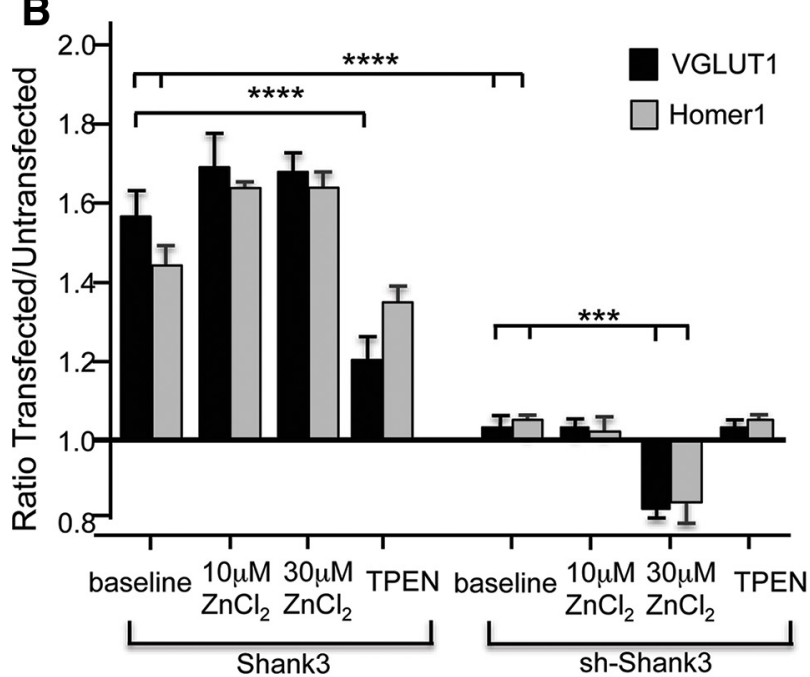

C

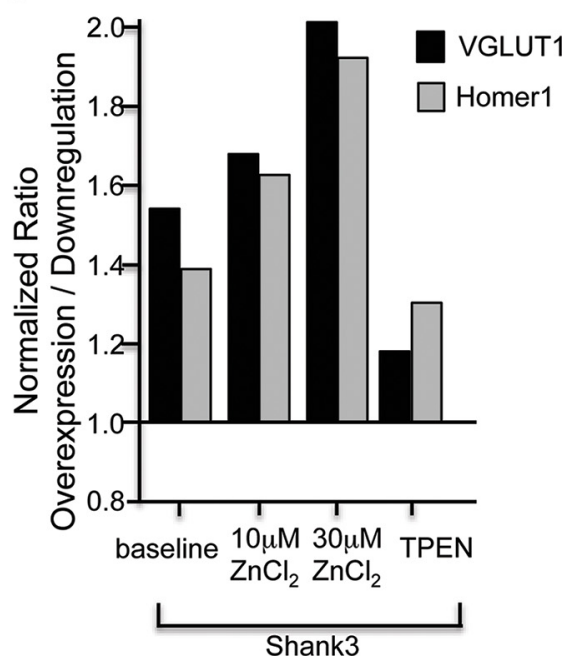

Figure 1. Zinc levels regulate Shank3 trans-synaptic signaling. A, Example images of hippocampal neurons expressing WT-Shank3 (left two panels) or sh-Shank3 (right two panels) and immunostained for VGLUT1 and Homer. The color merge images for each transfection condition show EGFP-Shank3 (green), VGLUT1 (Alexa Fluor 568, shown in red), and Homer (Alexa Fluor 647, shown in blue) puncta. $\boldsymbol{B}$, Trans-synaptic signaling quantification of VGLUT1 (gray bars) and Homer (black bars) levels expressed as a ratio of transfected over untransfected neurons (Arons et al., 2012). Neurons expressing either WT-Shank3 or sh-Shank3 were untreated (baseline) or treated with 10 or $30 \mu \mathrm{m} \mathrm{ZnCl}_{2}$ or $10 \mu \mathrm{m}$ TPEN for 30 min before fixation and immunostaining. Treatment with TPEN induced a significant decrease in both VGLUT1 and Homer in Shank3-expressing neurons compared with elevated zinc ( $\left.{ }^{* * * *} p<0.0001\right)$ and also a decrease in VGLUT1 compared with baseline $\left({ }^{* * * *} p<0.0001\right)$. Expression of sh-Shank3 induced a significant decrease in VGLUT1 and Homer compared with neurons expressing WT-Shank3 $\left({ }^{* * *} p<0.0001\right)$ and treatment with 30 $\mu \mathrm{M} \mathrm{ZnCl}_{2}$ further significantly reduced VGLUT1 and Homer compared with baseline levels ( $\left.{ }^{* *} p<0.001\right)$. C, Normalized ratio of VGLUT1 and Homer in WT-Shank3-overexpressing neurons to neurons expressing sh-Shank3 in baseline (untreated) neurons and in neurons treated with 10 or $30 \mu \mathrm{m}$ zinc or $10 \mu \mathrm{M}$ TPEN.

ings between primary hippocampal pyramidal neurons. In control untransfected neurons, within 5 min of zinc application (10 $\mu \mathrm{M} \mathrm{ZnCl}_{2}$ ), the average AMPAR EPSC amplitude increased significantly to $130.0 \pm 12.9 \%$ of baseline current amplitude (Fig. $2 A ; n=8$ paired recordings; $p<0.001)$. AMPAR EPSC amplitude remained potentiated for the duration of the zinc application (15 min), but was not maintained upon zinc removal (Fig. $2 A$ ). Intriguingly, zinc-induced potentiation of synaptic transmission was dependent on Shank3 because neurons in which Shank3 expression had been eliminated by sh-Shank3 were not responsive to zinc application (Fig. 2A; average amplitude in the presence of zinc was $94.7 \pm 5.3 \%$ of baseline current amplitude; $n=7$ paired recordings).

We next examined how overexpression of Shank3 influences zinc-dependent regulation of AMPAR-mediated synaptic transmission. As described previously, AMPAR EPSC amplitudes in neurons expressing WT-Shank3 were significantly larger than in control/untransfected neurons due to enhanced presynaptic and postsynaptic function (Arons et al., 2012; Fig. 2B). Application of $10 \mu \mathrm{M} \mathrm{ZnCl}{ }_{2}$ failed to further increase AMPAR EPSC amplitude ( $n=8$ paired recordings, Fig. $2 A, B$ ). We hypothesized that a potentiating effect of zinc on synaptic transmission in these neurons could be occluded by the larger baseline AMPAR EPSC amplitudes induced by WT-Shank3 (Arons et al., 2012; Fig. 2B). We therefore examined whether prior chelation with TPEN could unmask zinc responsiveness. In control neurons, chelation of zinc with TPEN application $(10 \mu \mathrm{M})$ induced a significant depression in AMPAR EPSC amplitude (average amplitude in the presence of TPEN was $73.8 \pm 2.5 \%$ of baseline; $n=18$ paired recordings; $p<0.001$; Fig. $2 C$ ), showing that zinc is required for maintaining baseline AMPAR-mediated synaptic transmission. In WT-Shank3-expressing neurons, zinc chelation also signifi- 


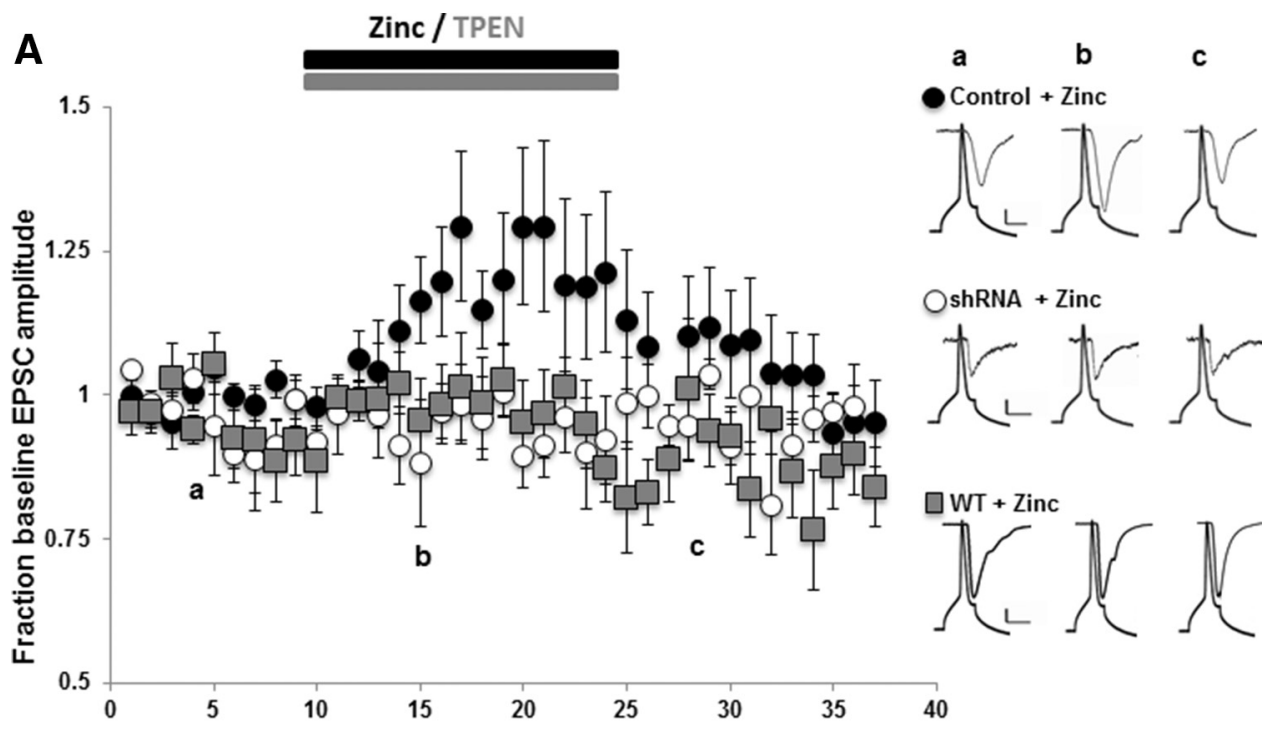

Time (minutes)

B

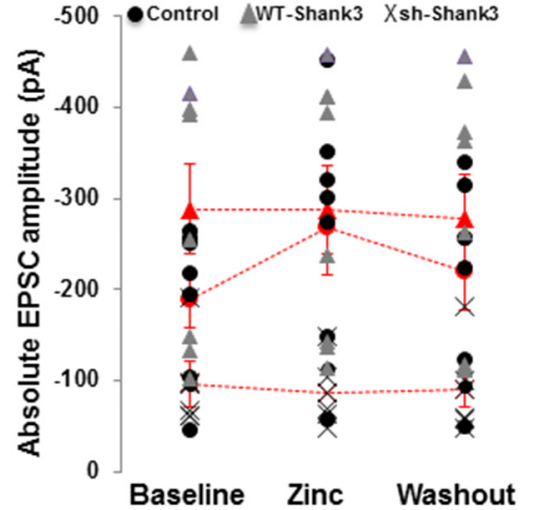

C

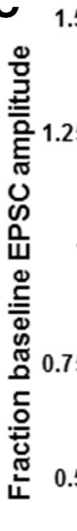

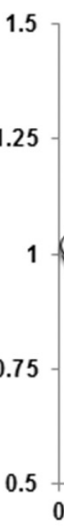<smiles>CC1CC1(C)C</smiles><smiles>C1CC2(C1)CC2</smiles><smiles>CC1=CC(C)=C1</smiles><smiles>C[Si]1(C)CC1</smiles>
Zinc TPEN<smiles>C1=[Al]C[Al]1</smiles>
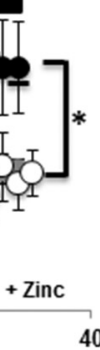

40

Figure 2. Acute changes in zinc concentration regulate AMPAR EPSC amplitudes in a Shank3-dependent manner. $A$, Average AMPAR EPSC amplitudes from paired whole-cell recordings between excitatory pyramidal neurons normalized to baseline (pre-zinc) amplitude. Zinc $\left(\mathrm{ZnCl}_{2}, 10 \mu \mathrm{M}\right)$ was bath applied to control untransfected neurons (black circles), neurons expressing WT-Shank3 (gray squares), and neurons in which Shank3 expression was knocked down by shRNA (white circles). Zinc application significantly increased AMPAR EPSC amplitudes in control untransfected neurons, but not in neurons that lacked Shank3 or in neurons that overexpressed WT-Shank3. Right, Example presynaptic action potentials and postsynaptic AMPAR EPSC traces from control + zinc, shRNA + zinc, and WT-Shank3 + zinc. Letters a-c denote when example traces were collected. Scale bar, $10 \mathrm{mV} / 20 \mathrm{pA} / 10 \mathrm{~ms}$ for controls, $10 \mathrm{mV} / 10 \mathrm{pA} / 10 \mathrm{~ms}$ for sh-Shank3, and $10 \mathrm{mV} / 75 \mathrm{pA} / 10$ ms for WT-Shank3. B, Absolute average peak AMPAR EPSC amplitudes from each paired recording before, during, and after zinc application in control (black circles), WT-Shank3 (gray triangles) and sh-Shank3 $(X)$ expressing neurons. The pooled average AMPAR EPSC amplitude is shown for each group in red (circles $=$ controls, triangles $=$ WT-Shank3, $X=$ sh-Shank3). Note the higher amplitude currents in WT-Shank3 neurons and the lower current amplitudes in sh-Shank3-expressing neurons. C, Application of TPEN to chelate zinc decreases AMPAR EPSC amplitudes in control untransfected and WT-Shank3-expressing neurons and unmasks zinc responsiveness in WT-Shank3-expressing neurons. Plotted are average AMPAR EPSC amplitudes in response to TPEN application for $10 \mathrm{~min}$ (control: white circles, WT-Shank3: gray and black circles). After TPEN washout, paired recordings were either continued for a further 20 min (white and gray circles), during which time AMPAR EPSC amplitudes remained significantly depressed, or zinc (10 $\mu \mathrm{m}$ ) was bath applied to WT-Shank3 neurons at $25 \mathrm{~min}$ for $10 \mathrm{~min}$ (black circles). Application of zinc after TPEN resulted in a significant increase ( ${ }^{*} p<0.001$ ) in AMPAR EPSC amplitude back to baseline (maximal) levels. Inset, Example paired recording traces showing presynaptic action potentials and postsynaptic AMPAR EPSCs before (left), during (middle), and after (right) TPEN application and during zinc application (far right, black circles). Scale bar, $20 \mathrm{mV} / 75 \mathrm{pA} / 20 \mathrm{~ms}$.

cantly decreased AMPAR EPSC amplitude $(p<0.001)$ with a maximal decrease in AMPAR EPSC amplitude to $68.1 \%$ of baseline (Fig. 2C). AMPAR EPSC amplitude remained depressed for the length of the paired recordings ( $\sim 35 \mathrm{~min}$; Fig. $2 C ; n=10$ pairs). Application of zinc to WT-Shank3-expressing neurons after TPEN application then enabled a significant zinc-induced increase in AMPAR EPSC amplitude back to baseline (i.e., maximal) levels (Fig. $2 C ; n=8$ paired recordings; $p<0.001$ ).

\section{Zinc regulates the dynamics of Shank 3 within} dendritic spines

The ability of zinc to bind the SAM domain in Shank3 (Baron et al., 2006) and modulate Shank 3 dependent trans-synaptic signaling and
AMPAR-mediated synaptic transmission (Figs. 1,2) implies that zinc might regulate the activation of Shank 3 directly within dendritic spines. Conceptually, such a transition could involve a change in the conformational state of Shank 3 and its subsequent assembly into a PSD-associated signaling complex.

To assess whether the dynamics of Shank3 are regulated by zinc, we used FRAP to define both the kinetics of exchanges and the fraction of EGFP-Shank 3 within dendritic spines that exists in bound and mobile states. The recovery of bleached EGFP-Shank3 puncta were monitored for a $45 \mathrm{~min}$ period (Fig. $3 A$ ). Under basal conditions, $\sim 60 \%$ of EGFP-Shank 3 recovered in this time frame. In contrast, the presence of $30 \mu \mathrm{M} \mathrm{ZnCl}_{2}$ or $10 \mu \mathrm{M}$ TPEN 


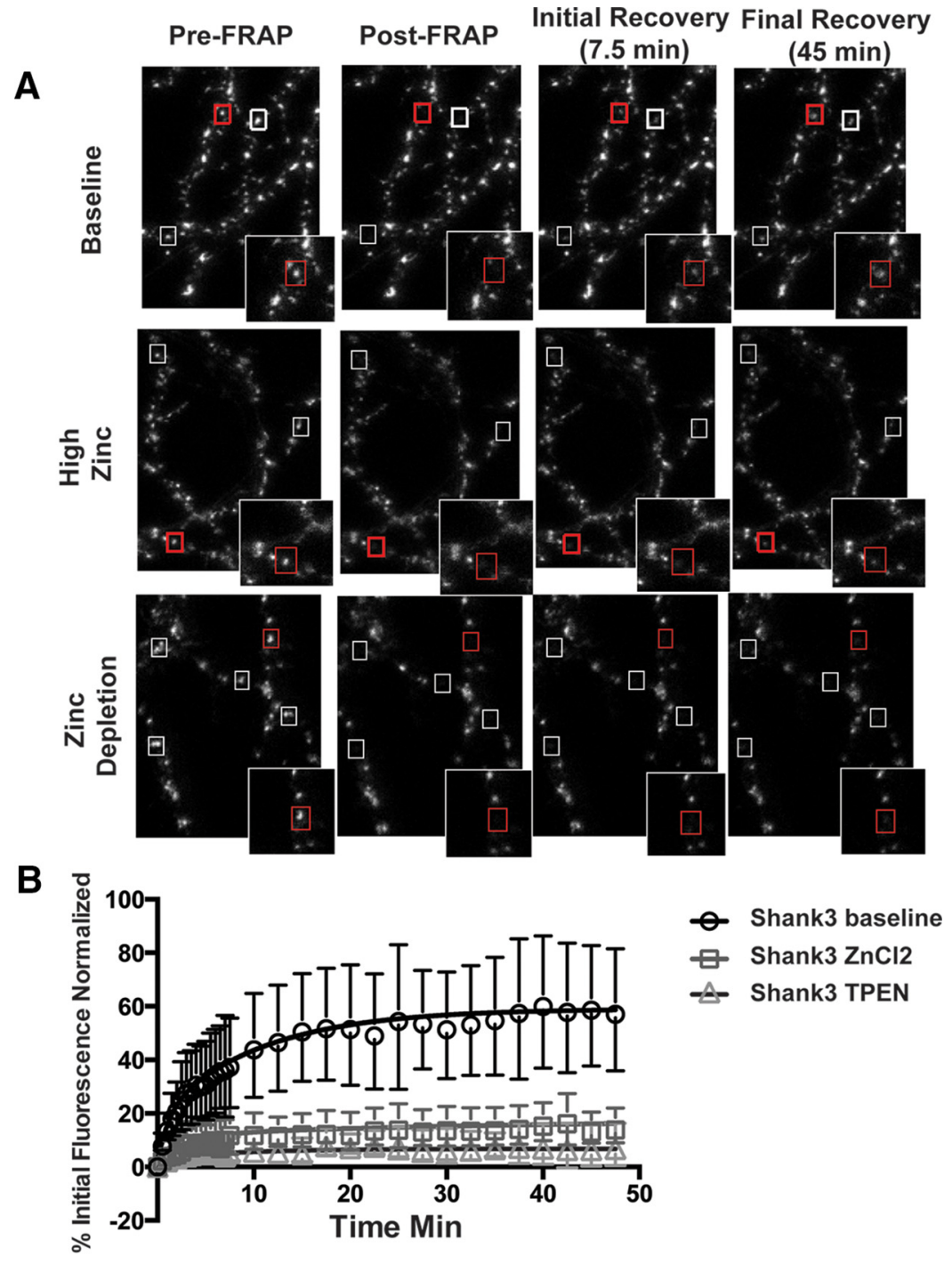

C

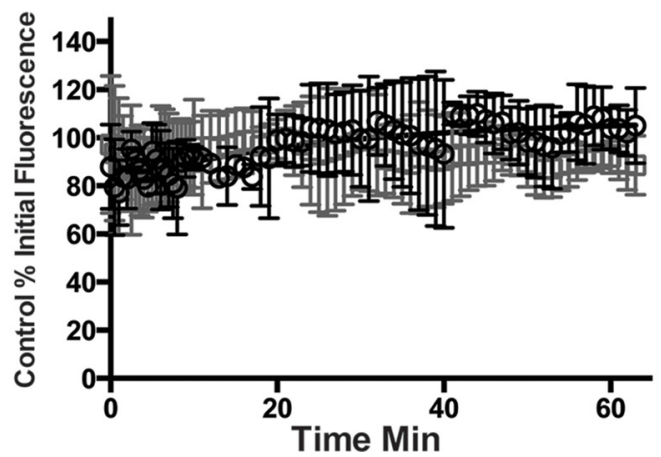

Figure 3. Shank3 dynamics are regulated by zinc. $A$, Top, Representative images of EGFP-Shank3 puncta from neurons imaged at DIV14 -16. In these FRAP experiments, three images were acquired to set baseline (Pre-FRAP column). Five-six puncta (boxed) were then selected per field of view and bleached to $<20 \%$ of initial fluorescence value (Post-FRAP column). Fluorescence recovery at these synapses was monitored for the next $45 \mathrm{~min}$. Example images at 7.5 and $45 \mathrm{~min}$ are shown. Insets show puncta in red boxes at higher magnification. Middle, Images of EGFP-Shank3-expressing neurons treated with $30 \mu \mathrm{m} \mathrm{ZnCl}$ (high zinc) throughout the experiment. Bottom, EGFP-Shank3-expressing neurons treated with $10 \mu \mathrm{m}$ of the zinc chelator TPEN (zinc depletion). B, Quantification of FRAP recovery curves for EGFP-Shank3 synaptic puncta in normal (baseline), high ( $\left.30 \mu \mathrm{M} \mathrm{ZnCl}_{2}\right)$, or low (TPEN) zinc. C, Changes in the synaptic level of EGFP-Shank3 after the acute addition of $30 \mu \mathrm{m} \mathrm{ZnCl}$ or $10 \mu \mathrm{m}$ TPEN. Fluorescent intensity values were monitored over the course of $70 \mathrm{~min}$ as in FRAP experiments. As in untreated, values decrease between $10 \%$ and $15 \%$, indicating that depleting zinc does not cause a dramatic loss of Shank3 from synapses, but rather a stabilization within dendritic spines. in the Tyrode's buffer dramatically reduced the fraction of initial fluorescence that recovered during the $45 \mathrm{~min}$ period to $12 \%$ and $6 \%$, respectively (Fig. $3 B$ ).

Analyzing the exponential components of the recovery curves (Tsuriel et al., 2006) revealed that EGFP-Shank3 recovery in the absence of any additionally added zinc was characterized by a fast component $\left(\tau_{1}=3.7 \mathrm{~min}\right)$ and a slow component $\left(\tau_{2}=130 \mathrm{~min}\right)$ that represented $\sim 58 \%$ of the entire fluorescence. These data indicate that the majority of Shank3 exposed to zinc during growth is in a highly mobile pool, which quickly exchanges with extrasynaptic EGFPShank3, whereas $\sim 42 \%$ is immobilized within spines, presumably by its association with the PSD. When $30 \mu \mathrm{M} \mathrm{ZnCl}_{2}$ was included in the imaging buffer, the fraction of immobile EGFP-Shank3 increased to $88 \%$, indicating that zinc facilitates the association of Shank3 with, for example, the $\operatorname{PSD}\left(\tau_{1}=3.4 \mathrm{~min}, \tau_{2}=1700 \mathrm{~min}\right.$, \% fast $=12 \%)$.

Surprisingly, the addition of $10 \mu \mathrm{M}$ TPEN also caused a dramatic stabilization of EGFP-Shank3 within dendritic spines, with $94 \%$ entering into an immobilized pool under conditions that deplete neurons/synapses of zinc $\left(\tau_{1}=2.9 \mathrm{~min}, \tau_{2}=\right.$ $3000 \mathrm{~min}, \%$ fast $=6 \%$ ). This result was counterintuitive because we anticipated that the removal of zinc would have increased the pool of EGFP-Shank3 in the fast exchange component $\tau_{1}$. One explanation is that depleting zinc places most of EGFP-Shank3 into an inactive state that is not retained in dendritic spines (Grabrucker et al., 2011b), leaving only a small, zinc-insensitive pool of EGFP-Shank3 at the synapse. Alternatively, zinc depletion not only inactivates Shank3, but also drives it into inactive protein aggregates that are retained within dendritic spines. To test this hypothesis, the fluorescence intensity of EGFPShank3 puncta was monitored for $70 \mathrm{~min}$ before and after acute treatment of neurons with either $30 \mu \mathrm{M}$ zinc or $10 \mu \mathrm{M}$ TPEN (Fig. 3C). Zinc supplementation caused a small increase in the average fluorescence intensity/synapse, whereas zinc depletion led to slight decreases $(\sim 10 \%$ difference) during this time period. These data indicate that acute changes in zinc do not cause dramatic changes in the spine levels of Shank3. These data, together with data demonstrating that TPEN addition blocks trans-synaptic increase in VGLUT1 and Homerlb (Fig. 1), suggest that, in the absence of synaptic zinc, most 
of Shank3 enters into a stabilized inactive state within spines (see model in Fig. 6).

ASD-associated Shank $3^{\mathrm{R} 87 \mathrm{C}}$ remains zinc sensitive

ASD-associated mutations in Shank3 impair synaptic transmission and, more specifically, presynaptic/postsynaptic coupling through Neurexin/Neuroligin (Arons et al., 2012). Shank 3 variants containing amino acid substitutions within the $\mathrm{N}$-terminal Ankyrin repeats localize properly at synapses (Durand et al., 2007; Arons et al., 2012), suggesting that the mechanism of inactivation is independent of synaptic localization. Given the prominent role for zinc in the activation of Shank3 (Figs. 1, 3), we considered whether Shank3 forms harboring single amino acid substitutions are functionally dead due to their inability to respond to zinc.

As an initial test of this hypothesis, we used FRAP to determine whether the zincsensitive dynamics of one of these mutant proteins, Shank $3^{\mathrm{R} 87 \mathrm{C}}$, was altered (Fig. $4 A$ ). In normal Tyrode's solution, the extent of recovery for synaptic EGFP-Shank $3^{\text {R87C }}$ revealed that less than half of the protein $(26 \%)$ is in a mobile pool and the majority is in an immobile pool $\left(\tau_{1}=3.9 \mathrm{~min}, \tau_{2}=\right.$ $60.9 \mathrm{~min}$ ). Zinc induced a dramatic stabilization of EGFP-Shank $3^{\text {R87C }}$ similar to wildtype (Figs. $3 B, 4 A$ ), with $30 \mu \mathrm{M}$ zinc shifting $96 \%$ of the molecules into an immobile state $\left(\tau_{1}=3.8 \mathrm{~min}, \tau_{2}=3400 \mathrm{~min}\right)$. Zinc depletion with TPEN increased the fraction of the R87C mutant in the immobile pool (96\% for $\left.\mathrm{R} 87 \mathrm{C} ; \tau_{1}=1.5 \mathrm{~min}, \tau_{2}=510 \mathrm{~min}\right)$. Overall, these experiments reveal that Shank $3^{\mathrm{R} 87 \mathrm{C}}$ remains zinc responsive.

\section{Zinc activation of Shank $3^{\mathrm{R} 87 \mathrm{C}}$ promotes functional postsynaptic but not presynaptic changes}

Conceptually, we anticipated that, although the dynamics are qualitatively different, as in wild-type Shank3, elevating zinc should push Shank $3^{\mathrm{R} 87 \mathrm{C}}$ into an open/active conformation that becomes incorporated into the PSD, whereas zinc depletion would push a significant fraction into an immobile inactive state. To explore this possibility, we investigated whether the addition of zinc promotes the recruitment of the Shank3-binding partner Homer $1 \mathrm{~b}$ into dendritic spines and triggers a trans-synaptic increase in VGLUT1 (Fig. $4 B-D$ ). As reported previously, in normal Tyrode's solution (no added zinc), the Shank3 $3^{\text {R87C }}$ mutant appeared to be functionally dead because the levels of Homer1b and VGLUT1 at synapses expressing this molecule are no different from untransfected neurons (Fig. 4C). After $20 \mathrm{~min}$ in 10 or $30 \mu \mathrm{M} \mathrm{ZnCl}$, the postsynaptic levels of Homer1b were rescued to wild-type EGFP-Shank3 levels (Fig. $4 C)$, suggesting that zinc can indeed activate Shank $3^{\mathrm{R} 87 \mathrm{C}}$, allowing it to recruit its postsynaptic binding partners into dendritic spines. However, zinc treatment had no effect on the presynaptic levels of VGLUT1, indicating that it was still unable to elicit a trans-synaptic signal.
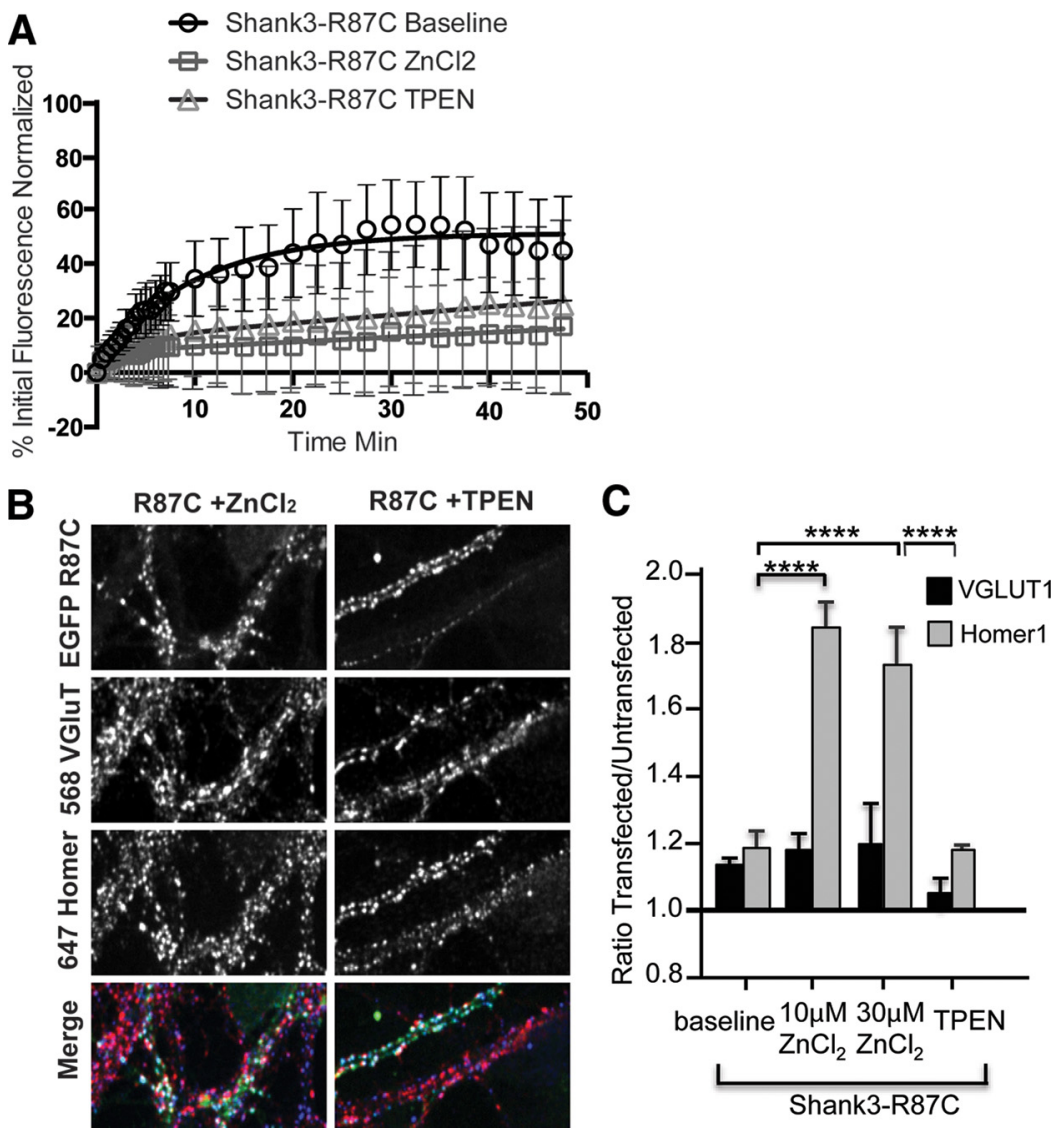

Figure 4. Shank $3^{\mathrm{R} 7 \mathrm{C} C}$ retains zinc responsiveness. $\boldsymbol{A}$, Plotted rates of FRAP of EGFP-Shank $3^{\mathrm{R} 7 \mathrm{C}}$ puncta in control conditions mmobile Shank $3^{R 87 C}$, indicating that it is still zinc responsive. $\boldsymbol{B}$, Example images of hippocampal neurons transfected with Shank3 ${ }^{\text {R87C }}$ and immunostained for VGLUT1 and Homer. The colored merge shows EGFP-Shank3 ${ }^{\text {R87C }}$, VGLUT1 (Alexa Fluor 568 ), and Homer (Alexa Fluor647, shownin blue) colocalized puncta.C, Trans-synapticsignaling quantification orVGLUT1 neurons expressing Shank $3^{\text {R87C }}$. The expression levels of VGLUT1 and Homer were significantly decreased in Shank $3^{\text {R87C }}$ expressing neurons compared with WT-Shank3-expressing neurons $(p<0.01)$. Both 10 and $30 \mu \mathrm{m}$ zinc led to significant increases in Homer levels in Shank3 ${ }^{\text {R87C }}$-expressing neurons $\left({ }^{* * * *} p<0.0001\right.$ ), but no significant increases were induced in VGLUT1 $(p>0.05)$. TPEN application reversed the increase in Homer levels in Shank $3^{\text {R87C }}$-expressing neurons $\left.{ }^{* * * *} p<0.0001\right)$.

Because Shank $3^{\mathrm{R} 87 \mathrm{C}}$ retains postsynaptic zinc responsiveness, we next investigated whether AMPAR-mediated synaptic transmission could be enhanced by zinc in neurons expressing EGFPShank $3^{\text {R87C }}$ (Fig. 5). Specifically, we observed that zinc was able to induce a significant increase in AMPAR EPSC amplitudes that was of the same magnitude in EGFP-Shank $3^{\mathrm{R} 87 \mathrm{C}}$-expressing neurons as was observed in control untransfected neurons (130.0 \pm $8.6 \%, n=10$ paired recordings, $p<0.001$; Fig. $5 A$ ). The potentiation was again not sustained after zinc removal (Fig. $5 A$ ).

The fact that trans-synaptic signaling could not be rescued by zinc (Fig. 4) suggests that the zinc-induced increase in AMPARmediated synaptic transmission in Shank $3^{\mathrm{R} 87 \mathrm{C}}$-expressing neurons is localized to the postsynapse. To test this hypothesis, we measured failure rates of AMPAR synaptic transmission (Fig. $5 B)$. Neurons expressing Shank $3^{\text {R87C }}$ showed a significantly higher failure rate $(21.7 \pm 4.37 \%)$ compared with control untransfected $(2.63 \pm 2.22 \%)$, Shank3 WT $(0 \%)$, or shRNAShank3-expressing neurons $(9.0 \pm 2.40 \% ; p<0.05$ in all cases $)$. However, no significant change in failure rate occurred in the presence of zinc (or TPEN) in any group (Fig. $5 B$; in zinc: Shank3 ${ }^{\text {R87C }}$ $24.57 \pm 6.56 \%$; control $2.63 \pm 2.12 \%$; Shank3 WT 0\%; sh-Shank3 $13.75 \pm 3.1 \% ; p>0.05$ in all cases), supporting the hypothesis that 


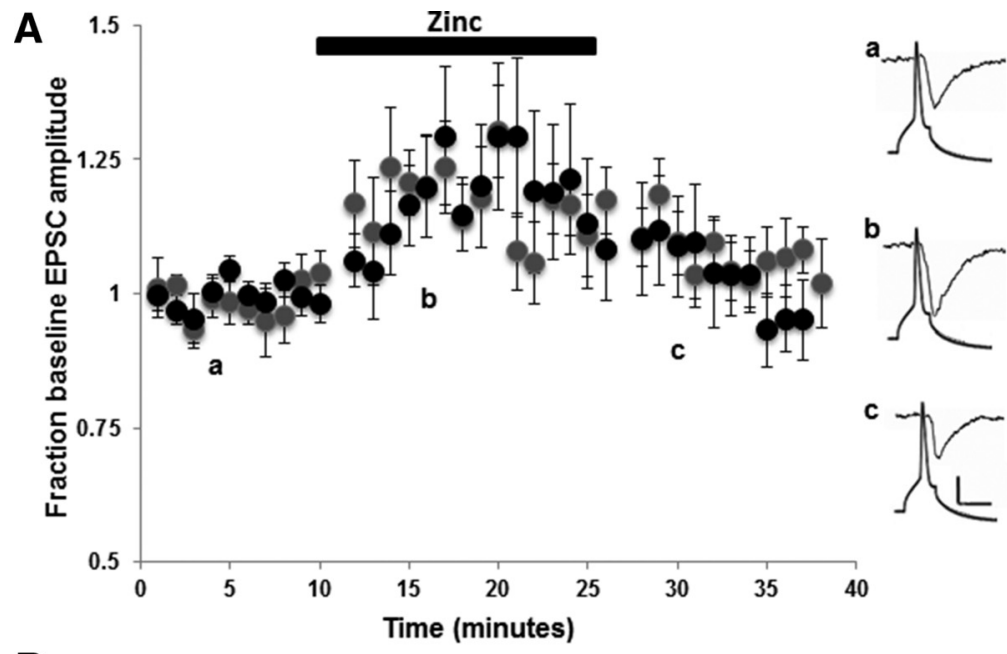

B

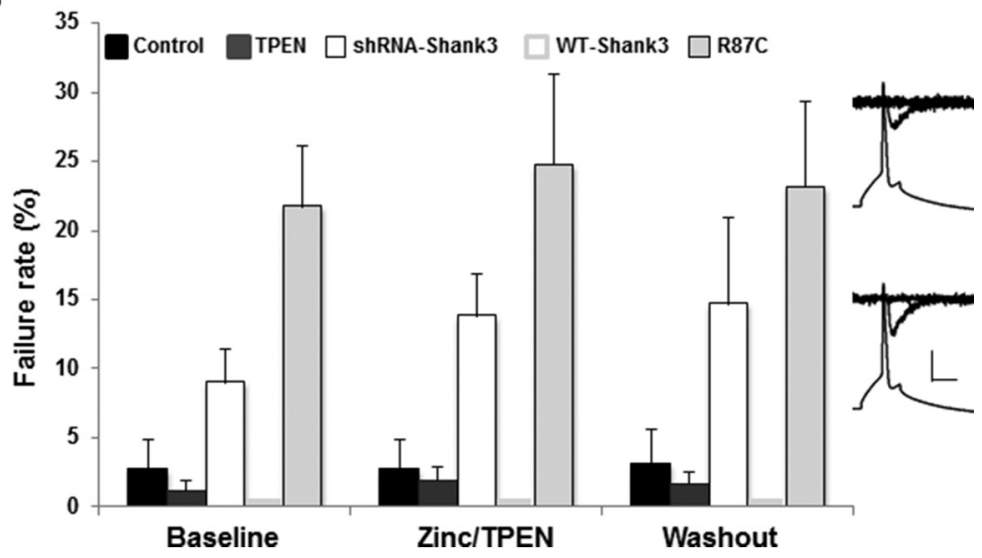

Figure 5. Neurons expressing Shank $3^{\mathrm{R} 8 \mathrm{C} C}$ retain their ability to respond to increases in zinc. $A$, Average AMPAR EPSC amplitudes from paired recordings between excitatory pyramidal neurons normalized to baseline (pre-zinc) amplitudes. Zinc $\left(\mathrm{ZnC}_{2}, 10 \mu \mathrm{M}\right)$ was applied for 15 min to Shank ${ }^{R 87 C}$-expressing neurons (gray circles). Also plotted for comparison are zincresponses in control neurons (from Fig. 2; black circles). AMPAR EPSC amplitudes in Shank ${ }^{\mathrm{R} 87 \mathrm{C}}$-expressing neurons respond to acute zinc similar to control neurons. Inset, Example presynaptic action potentials and postsynaptic AMPAR EPSC traces from Shank $3^{\mathrm{R} 87 \mathrm{C}}$-expressing neurons. Letters $a-c$ denote when example traces were collected. Scale bar, $20 \mathrm{mV} / 20 \mathrm{pA} / 20 \mathrm{~ms}$. B, AMPAR EPSC failure rates at baseline (before zinc/TPEN application), during zinc/TPEN application, and after zinc/TPEN washout in control untransfected neurons (zinc: black bars; TPEN: gray bars), shShank3expressing neurons (zinc, white bars), WT-Shank3-expressing neurons (zinc, light gray bars), and Shank $3^{\mathrm{R} 7 \mathrm{C}}$-expressing neurons (zinc, mid-gray bars). Note that the failure rate was 0 for all WT-Shank3 recordings. No significant changes in failure rate occurred with the application of zinc or TPEN in any experimental group ( $p>0.05$ in all cases). Right, Example AMPAR EPSCs and failures of synaptic transmission in shRNA-Shank3-expressing neurons (top) and Shank $3^{\text {R87C }}$-expressing neurons (bottom). Shown are three consecutive traces overlaid for each transfection. Scale bar, $20 \mathrm{mV} / 25 \mathrm{pA} / 20 \mathrm{~ms}$.

zinc-dependent changes in synaptic function under these conditions primarily have a postsynaptic locus. These data also show the R87C mutation primarily affects trans-synaptic signaling at excitatory synapses, not the ability of zinc to modulate AMPAR-mediated synaptic transmission via Shank3.

\section{Discussion}

In the current study, our data reveal that zinc regulates the dynamic properties of Shank3, as well as AMPAR-mediated synaptic transmission, in a Shank3-dependent manner. We also found that the ASD-associated Shank $3^{\mathrm{R} 87 \mathrm{C}}$ retains its zinc sensitivity and zincsensitive facets of synaptic transmission, but remains incapable of trans-synaptic signaling. These data indicate that Shank3 regulates zinc-sensitive aspects of synaptic transmission.

\section{Zinc modulates Shank3 dynamics in dendritic spines}

Previous studies on Shank3 have shown that its synaptic localization was dependent on its C-terminal SAM domain (Boeckers et al., 2005). Subsequent studies showed that the SAM domain can assemble in vitro into higher-order oligomers with a complexity that is influenced by zinc binding (Baron et al., 2006). This latter study also found that the synaptic localization of the SAM domain was zinc sensitive, leading to the hypothesis that Shank3 might use this characteristic to build a stable platform within dendritic spines (Baron et al., 2006; Gundelfinger et al., 2006). A role for zinc in promoting the synaptic localization of endogenous Shank3 has also been investigated (Grabrucker et al., 2011b), but a role in the activation of Shank3, changes in synaptic transmission, or the assembly of stable platforms has not been explored.

In the current study, we investigated whether the functional activation of Shank3 was modulated by zinc. Here, we found that manipulating exogenous levels of zinc affected the synaptic levels of VGLUT1 and Homerlb in a Shank3dependent manner. Specifically, elevating zinc from $0.67 \mu \mathrm{M}$ to 10 or $30 \mu \mathrm{M}$ increased the synaptic levels of VGLUT1 and Homer1b, whereas depleting zinc with $10 \mu \mathrm{M}$ TPEN suppressed these levels. Intriguingly, we also found that zinc manipulation altered the dynamic properties of EGFP-tagged Shank3 within dendritic spines. For example, similar to previous studies (Tsuriel et al., 2006), we found that, at baseline, a significant fraction $(60 \%)$ of EGFP-Shank3 was in a highly mobile state that exchanged with a time constant of $\sim 2$ min, whereas the remainder was less mobile with an exchange constant of $\sim 130 \mathrm{~min}$. The addition of $\mathrm{ZnCl}_{2}$ had a profound effect on these dynamics, shifting nearly all of the synaptically localized molecules into a highly stable pool $\left(\tau_{2}\right.$ $=1700 \mathrm{~min}$ ). This stable pool could reflect the fact that zinc promotes a conformation change in Shank3, allowing for its tight association with other PSD-associated proteins. Importantly, we observed a tight correlation between enhanced trans-synaptic signaling and the increased immobilization of EGFP-Shank3 in the presence of elevated zinc. These data are consistent with a model (Fig. 6) in which elevated spine zinc not only activates Shank3, but also promotes the recruitment of Homer1b, AMPARs, and trans-synaptic Neuroligin/Neurexin complexes into PSDs. At present, Shank3 appears to be a primary zinc sensor within the PSD, a property not shared by Shank1. Consistently, mutations in the Shank3 SAM domain block its synaptic localization (Baron et al., 2006). Moreover, whereas the SAM domain alone from Shank3 exhibits zinc sensitivity, the SAM domain from Shank1 does not (Grabrucker et al., 2011b). Future studies examining the differences within the Shank1 and Shank3 SAM domains and their involvement in zinc-sensitive recruitment of other PSD proteins will be of significant interest.

Surprisingly, the addition of TPEN also caused a dramatic immobilization of EGFP-Shank3 (Fig. 3). This was associated 


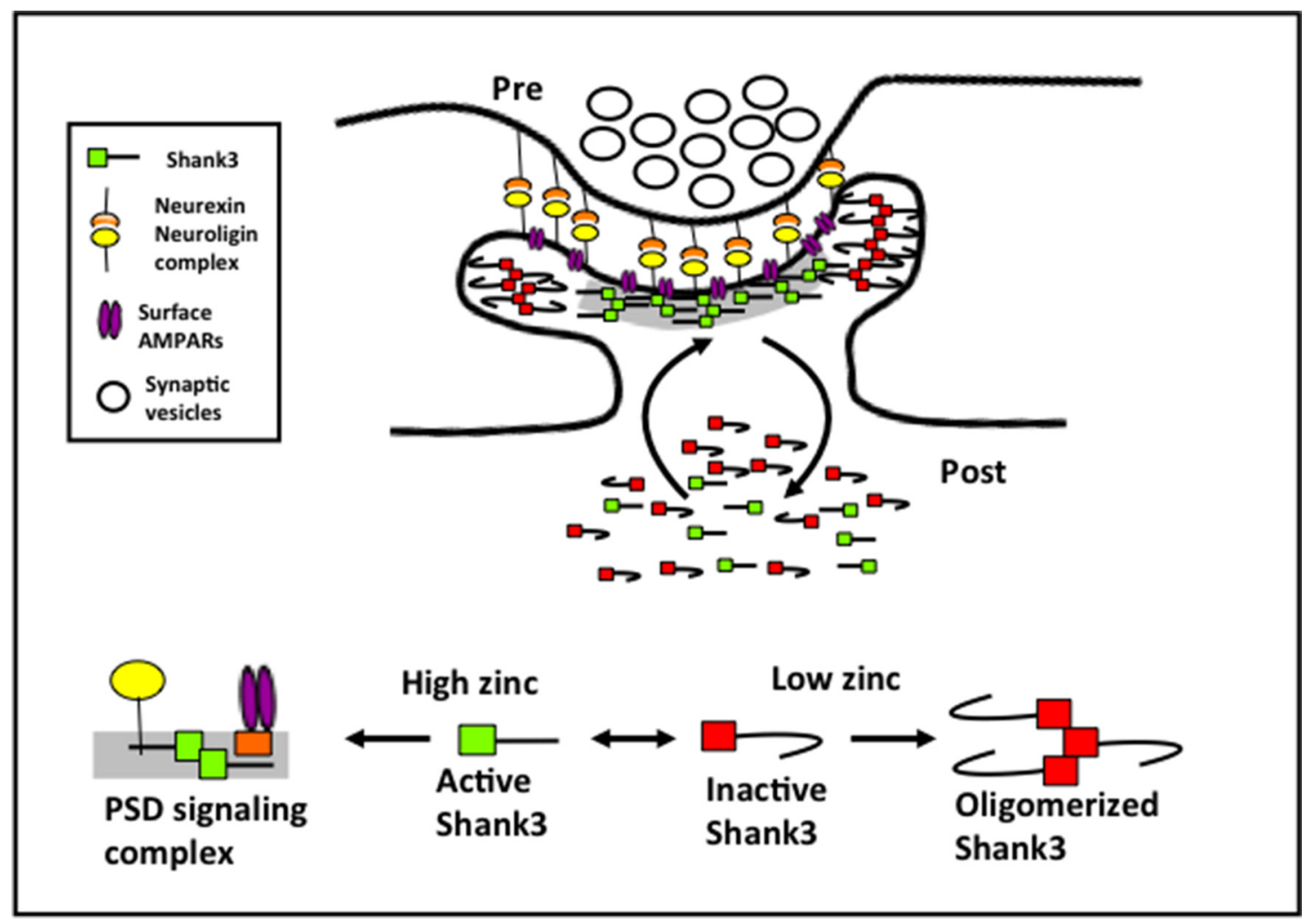

Figure 6. Model of zinc-dependent regulation of Shank3 dynamics and activation state. Our data suggest that zinc changes the conformation and association of Shank3 within dendritic spines, resulting in Shank3, which dynamically exchanges between three pools. In pool 1, Shank3 is in an active conformation in the presence of higher zinc (green squares). This conformation assembles into an active signaling complex that includes Homer, AMPARs, and Neuroligin, leading to enhanced synaptic transmission. When zinc levels are low, Shank 3 is inactive and resides in two additional pools: one that is rapidly exchanging (red squares) and one that contains oligomerized Shank3 (bound red squares). Oligomerization is potentially mediated by its SAM domain. We propose that, during synaptic transmission, zinc released from vesicles or from intracellular stores could lead to real-time changes in synaptic strength through the recruitment of activated Shank3 into the PSD.

with a modest change in Shank3 levels $(\sim 10 \%)$, which may reflect plasmid overexpression of Shank3, creating a larger pool of extrasynaptic Shank3 that masks changes in synaptic levels. However, our observed changes were similar to those seen for endogenous Shank3 (Grabrucker et al., 2014). Functionally, the decreased mobility associated with the addition of TPEN was inversely correlated to AMPAR-mediated synaptic transmission and the synaptic levels of VGLUT1 and Homer1b. This implies that low/no zinc drives most Shank3 into an immobilized, inactive state (Fig. 6). At present, how Shank3 becomes immobilized in low zinc is unclear. One possibility is that it becomes bound to a stable structure such as the PSD. Alternatively, because the SAM domain can form stable filaments in the absence of zinc (Baron et al., 2006), Shank3 may use the ability of its SAM domain to polymerize into higher-order structures in a zinc-independent manner to sequester Shank3 within spines but away from the PSD. Immuno-EM and molecular replacement of the SAM domain should help to resolve this conundrum. The model shown in Figure 6 provides a visual representation of how postsynaptic zinc levels could modulate the dynamics and activation state of Shank3. Here, zinc activation is posited to promote its assembly into a signaling complex within the PSD, whereas zinc depletion results in its sequestration into an inactive oligomerized state.

Zinc modulation of synaptic function

Although not well appreciated, zinc is a potent signaling molecule that regulates synaptic transmission and plasticity in the hippocampus (Westbrook and Mayer, 1987; Mayer and Vyklicky, 1989; Lu et al., 2000; Li et al., 2001; Izumi et al., 2006; Takeda et al., 2009; Lorca et al., 2011; Pan et al., 2011). Our electrophysiological measurements support the concept that AMPARmediated synaptic transmission can be modulated by zinc. Mechanistically, such changes could be mediated by a variety of presynaptic and/or postsynaptic zinc-binding proteins, including Shank2 and Shank3 (Boeckers et al., 2005; Baron et al., 2006). However, our experiments show that postsynaptic Shank3 expression at excitatory synapses is required for the potentiating effect of zinc on synaptic transmission. Our data suggest that the ongoing expression of Shank2 is insufficient to mediate zinc-responsive AMPARmediated synaptic transmission and thus must play some other zincsensitive role within dendritic spines, such as in the initial assembly of excitatory synapses (Grabrucker et al., 2011b; Jiang and Ehlers, 2013; Schneider et al., 2014). How Shank3 drives zinc responsiveness to change AMPAR-mediated synaptic transmission dynamically is currently unknown. Shank3 is known to play a critical role in maintaining postsynaptic pools of both AMPARs and NMDARs (Bozdagi et al., 2010; Peça et al., 2011; Arons et al., 2012; Kouser et al., 2013; Duffney et al., 2015; Lee et al., 2015; Speed et al., 2015), as well as trans-synaptic increases in presynaptic function (Arons et al., 2012). Intriguingly, modulating zinc levels primarily affected the amplitude of AMPAR-mediated EPSCs. The lack of change in synaptic failure rates, which is coupled to changes in presynaptic release probability, supports the conclusion that the zinc-induced changes in synaptic transmission are primarily caused by changes in postsynaptic function.

Postsynaptic actions of zinc are further supported by the analysis of synapses expressing the ASD-associated Shank $3^{\mathrm{R} 87 \mathrm{C}}$ variant. Increases in extracellular zinc rescued the loss of function effects of this 
altered protein, enabling zinc-mediated increases in AMPARmediated synaptic transmission. However, because elevated zinclevels did not enhance the levels of VGLUT1 in presynaptic boutons formed onto neurons expressing GFP-Shank $3^{\mathrm{R} 87 \mathrm{C}}$, nor did they reduce the failure rates of synaptic transmission, this mutation does impair its ability to signal trans-synaptically even with enhanced zinc levels. Moreover, acute addition/depletion of zinc causes a dramatic change in the fraction in mobile and immobile pools of Shank $3^{\mathrm{R} 87 \mathrm{C}}$ (Fig. 4). Like wild-type Shank3, increasing zinc levels from 0.6 to 10 $\mu \mathrm{M}$ activates Shank $3^{\mathrm{R} 87 \mathrm{C}}$ and promotes the recruitment of the postsynaptic Shank3-binding partner Homerlb into dendritic spines. This amino acid exchange therefore does not appear to affect the zinc sensitivity of Shank3.

An important unresolved question is what role Shank3 and zinc play in synaptic transmission. Studies of synaptic plasticity at CA1 synapses have found that zinc has a profound effect on the induction of LTP, but not its maintenance (Izumi et al., 2006; Takeda et al., 2010; Lorca et al., 2011). Moreover, synapses lacking Shank3 fail to undergo LTP (Bozdagi et al., 2010; Wang et al., 2011; Kouser et al., 2013; Speed et al., 2015), suggesting that zinc and Shank3 may operate in concert to regulate this facet of synaptic plasticity. Although this is a provocative concept, our data indicate that acute zinc alone is insufficient to induce long-lasting forms of plasticity because AMPAR-mediated currents returned to baseline within minutes of its removal. A likely partner is the coactivation of NMDARs, known to be critical for the induction of LTP (Herron et al., 1986; Wigstrom and Gustafsson, 1986). Zinc-dependent activation of Shank3 could therefore promote increased AMPAR recruitment to synapses, similar to what is known to occur with actin polymerization (Allison et al., 1998; Durand et al., 2012; Duffney et al., 2015) and the expression of LTP (Shi et al., 1999; Oh et al., 2006; Jaskolski et al., 2009; Makino and Malinow, 2009; Jurado et al., 2013; Zheng et al., 2015). However, because zinc influences the strength of synaptic transmission and Shank3 dynamics in a rapid and reversible manner, the underlying mechanisms may differ from those induced during persistent changes in synaptic strength and structure.

In summary, our studies reveal that Shank3 not only senses changes in postsynaptic zinc, but also is a key component of a zincsensitive signaling pathway at excitatory synapses. Importantly, zinc homeostasis is disrupted in neuropsychiatric disorders including ASD (Curtis and Patel, 2008; Grabrucker et al., 2011a; Russo and Devito, 2011; Yasuda et al., 2011). Elevation of zinc has been shown to rescue normal social interaction via Src and NMDAR activation in Shank2 and Tbr1 ASD mouse models (Lee et al., 2015), whereas chronic zinc deficiency induces the loss of Shank2/3 and increases the incidence of ASD-related behaviors (Grabrucker et al., 2014). Together with our results, these data suggest that environmental/ dietary factors such as changes in zinc levels could alter the Shank3signaling system and reduce the optimal performance of Shank3dependent excitatory synaptic function. Therefore, strategies to activate this zinc-sensitive pathway could potentially restore the functionality of these synapses.

\section{References}

Allison DW, Gelfand VI, Spector I, Craig AM (1998) Role of actin in anchoring postsynaptic receptors in cultured hippocampal neurons: differential attachment of NMDA versus AMPA receptors. J Neuroscience 18: 2423-2436. Medline

Arons MH, Thynne CJ, Grabrucker AM, Li D, Schoen M, Cheyne JE, Boeckers TM, Montgomery JM, Garner CC (2012) Autism associated mutations in ProSAP2/Shank3 impair synaptic transmission and Neurexin-Neuroligin mediated transsynaptic signaling J Neurosci 32: 14966-14978. CrossRef
Assaf SY, Chung SH (1984) Release of endogenous Zn2+ from brain tissue during activity. Nature 308:734-736. CrossRef Medline

Baron MK, Boeckers TM, Vaida B, Faham S, Gingery M, Sawaya MR, Salyer D, Gundelfinger ED, Bowie JU (2006) An architectural framework that may lie at the core of the postsynaptic density. Science 311:531-535. CrossRef Medline

Boeckers TM, Bockmann J, Kreutz MR, Gundelfinger ED (2002) ProSAP/ Shank proteins: a family of higher order organizing molecules of the postsynaptic density with an emerging role in human neurological disease. J Neurochem 81:903-910. CrossRef Medline

Boeckers TM, Liedtke T, Spilker C, Dresbach T, Bockmann J, Kreutz MR, Gundelfinger ED (2005) C-terminal synaptic targeting elements for postsynaptic density proteins ProSAP1/Shank2 and ProSAP2/Shank3. J Neurochem 92:519-524. CrossRef Medline

Bozdagi O, Sakurai T, Papapetrou D, Wang X, Dickstein DL, Takahashi N, Kajiwara Y, Yang M, Katz AM, Scattoni ML, Harris MJ, Saxena R, Silverman JL, Crawley JN, Zhou Q, Hof PR, Buxbaum JD (2010) Haploinsufficiency of the autism-associated Shank3 gene leads to deficits in synaptic function, social interaction, and social communication. Mol Autism 1:15. CrossRef Medline

Curtis LT, Patel K (2008) Nutritional and environmental approaches to preventing and treating autism and attention deficit hyperactivity disorder (ADHD): a review. J Altern Complement Med 14:79-85. CrossRef Medline

Duffney LJ, Zhong P, Wei J, Matas E, Cheng J, Qin L, Ma K, Dietz DM, Kajiwara Y, Buxbaum JD, Yan Z (2015) Autism-like deficits in Shank3deficient mice are rescued by targeting actin regulators. Cell Rep 11:14001413. CrossRef Medline

Durand CM et al. (2007) Mutations in the gene encoding the synaptic scaffolding protein SHANK3 are associated with autism spectrum disorders. Nat Genet 39:25-27. CrossRef Medline

Durand CM, Perroy J, Loll F, Perrais D, Fagni L, Bourgeron T, Montcouquiol M, Sans N (2012) SHANK3 mutations identified in autism lead to modification of dendritic spine morphology via an actin-dependent mechanism. Mol Psychiatry 17:71-84. CrossRef Medline

Ebadi M, Murrin LC, Pfeiffer RF (1990) Hippocampal zinc thionein and pyridoxal phosphate modulate synaptic functions. Ann N Y Acad Sci 585: 189-201. CrossRef Medline

Goslin K, Schreyer DJ, Skene JH, Banker G (1988) Development of neuronal polarity: GAP-43 distinguishes axonal from dendritic growth cones. Nature 336:672-674. CrossRef Medline

Grabrucker AM, Rowan M, Garner CC (2011a) Brain-delivery of zinc-ions as potential treatment for neurological diseases: mini review. Drug Deliv Lett 1:13-23. Medline

Grabrucker AM, Knight MJ, Proepper C, Bockmann J, Joubert M, Rowan M, Nienhaus GU, Garner CC, Bowie JU, Kreutz MR, Gundelfinger ED, Boeckers TM (2011b) Concerted action of zinc and ProSAP/Shank in synaptogenesis and synapse maturation. EMBO J 30:569-581. CrossRef Medline

Grabrucker S, Jannetti L, Eckert M, Gaub S, Chhabra R, Pfaender S, Mangus K, Reddy PP, Rankovic V, Schmeisser MJ, Kreutz MR, Ehret G, Boeckers TM, Grabrucker AM (2014) Zinc deficiency dysregulates the synaptic ProSAP/Shank scaffold and might contribute to autism spectrum disorders. Brain 137:137-152. CrossRef Medline

Gundelfinger ED, Boeckers TM, Baron MK, Bowie JU (2006) A role for zinc in postsynaptic density asSAMbly and plasticity? Trends Biochem Sci 31:366-373. CrossRef Medline

Herron CE, Lester RA, Coan EJ, Collingridge GL (1986) Frequencydependent involvement of NMDA receptors in the hippocampus: a novel synaptic mechanism. Nature 322:265-268. CrossRef Medline

Howell GA, Welch MG, Frederickson CJ (1984) Stimulation-induced uptake and release of zinc in hippocampal slices. Nature 308:736-738. CrossRef Medline

Huang YZ, Pan E, Xiong ZQ, McNamara JO (2008) Zinc-mediated transactivation of TrkB potentiates the hippocampal mossy fiber-CA3 pyramid synapse. Neuron 57:546-558. CrossRef Medline

Inoue K, Branigan D, Xiong ZG (2010) Zinc-induced neurotoxicity mediated by transient receptor potential melastatin 7 channels. J Biol Chem 285:7430-7439. CrossRef Medline

Izumi Y, Auberson YP, Zorumski CF (2006) Zinc modulates bidirectional hippocampal plasticity by effects on NMDA receptors. J Neurosci 26: 7181-7188. CrossRef Medline 
Jaskolski F, Mayo-Martin B, Jane D, Henley JM (2009) Dynamindependent membrane drift recruits AMPA receptors to dendritic spines. J Biol Chem 284:12491-12503. CrossRef Medline

Jiang YH, Ehlers MD (2013) Modeling autism by SHANK gene mutations in mice. Neuron 78:8-27. CrossRef Medline

Jurado S, Goswami D, Zhang Y, Molina AJ, Sudhof TC, Malenka RC (2013) LTP requires a unique postsynaptic SNARE fusion machinery. Neuron 77:542-558. CrossRef Medline

Kim TY, Hwang JJ, Yun SH, Jung MW, Koh JY (2002) Augmentation by zinc of NMDA receptor-mediated synaptic responses in CA1 of rat hippocampal slices: mediation by Src family tyrosine kinases. Synapse 46 : 49-56. CrossRef Medline

Kouser M, Speed HE, Dewey CM, Reimers JM, Widman AJ, Gupta N, Liu S, Jaramillo TC, Bangash M, Xiao B, Worley PF, Powell CM (2013) Loss of predominant Shank3 isoforms results in hippocampus-dependent impairments in behavior and synaptic transmission. J Neurosci 33:1844818468. CrossRef Medline

Kreienkamp HJ (2008) Scaffolding proteins at the postsynaptic density: shank as the architectural framework. Handb Exp Pharmacol 186: 365-380. CrossRef Medline

Kumar RA, Christian SL (2009) Genetics of autism spectrum disorders. Curr Neurol Neurosci Rep 9:188-197. CrossRef Medline

Leal-Ortiz S, Waites CL, Terry-Lorenzo R, Zamorano P, Gundelfinger ED, Garner CC (2008) Piccolo modulation of Synapsinla dynamics regulates synaptic vesicle exocytosis. J Cell Biol 181:831-846. CrossRef Medline

Lee EJ, Choi SY, Kim E (2015) NMDA receptor dysfunction in autism spectrum disorders. Curr Opin Pharmacol 20:8-13. CrossRef Medline

Li D, Specht CG, Waites CL, Butler-Munro C, Leal-Ortiz S, Foote JW, Genoux D, Garner CC, Montgomery JM (2011) SAP97 directs NMDA receptor spine targeting and synaptic plasticity. J Physiol 589:4491-4510. CrossRef Medline

Li Y, Hough CJ, Suh SW, Sarvey JM, Frederickson CJ (2001) Rapid translocation of $\mathrm{Zn}(2+)$ from presynaptic terminals into postsynaptic hippocampal neurons after physiological stimulation. J Neurophysiol 86: 2597-2604. Medline

Lorca RA, Rozas C, Loyola S, Moreira-Ramos S, Zeise ML, Kirkwood A, Huidobro-Toro JP, Morales B (2011) Zinc enhances long-term potentiation through $\mathrm{P} 2 \mathrm{X}$ receptor modulation in the hippocampal CA1 region. Eur J Neurosci 33:1175-1185. CrossRef Medline

Lu YM, Taverna FA, Tu R, Ackerley CA, Wang YT, Roder J (2000) Endogenous $\mathrm{Zn}(2+)$ is required for the induction of long-term potentiation at rat hippocampal mossy fiber-CA3 synapses. Synapse 38:187-197. CrossRef Medline

Makino H, Malinow R (2009) AMPA receptor incorporation into synapses during LTP: the role of lateral movement and exocytosis. Neuron 64:381390. CrossRef Medline

Manzerra P, Behrens MM, Canzoniero LM, Wang XQ, Heidinger V, Ichinose T, Yu SP, Choi DW (2001) Zinc induces a Src family kinase-mediated up-regulation of NMDA receptor activity and excitotoxicity. Proc Natl Acad Sci U S A 98:11055-11061. CrossRef Medline

Masters BA, Quaife CJ, Erickson JC, Kelly EJ, Froelick GJ, Zambrowicz BP, Brinster RL, Palmiter RD (1994) Metallothionein III is expressed in neurons that sequester zinc in synaptic vesicles. J Neurosci 14:5844-5857. Medline

Mayer ML, Vyklicky L Jr (1989) The action of zinc on synaptic transmission and neuronal excitability in cultures of mouse hippocampus. J Physiol 415:351-365. CrossRef Medline

Meyer G, Varoqueaux F, Neeb A, Oschlies M, Brose N (2004) The complexity of PDZ domain-mediated interactions at glutamatergic synapses: a case study on Neuroligin. Neuropharmacology 47:724-733. CrossRef Medline

Miles JH (2011) Autism spectrum disorders: a genetics review. Genet Med 13:278-294. CrossRef Medline

Montgomery JM, Pavlidis P, Madison DV (2001) Pair recordings reveal allsilent synaptic connections and the postsynaptic expression of long-term potentiation. Neuron 29:691-701. CrossRef Medline

Oh MC, Derkach VA, Guire ES, Soderling TR (2006) Extrasynaptic membrane trafficking regulated by GluR1 serine 845 phosphorylation primes AMPA receptors for long-term potentiation. J Biol Chem 281:752-758. CrossRef Medline

Pan E, Zhang XA, Huang Z, Krezel A, Zhao M, Tinberg CE, Lippard SJ,
McNamara JO (2011) Vesicular zinc promotes presynaptic and inhibits postsynaptic long-term potentiation of mossy fiber-CA3 synapse. Neuron 71:1116-1126. CrossRef Medline

Paoletti P, Vergnano AM, Barbour B, Casado M (2009) Zinc at glutamatergic synapses. Neuroscience 158:126-136. CrossRef Medline

Pavlidis P, Madison DV (1999) Synaptic transmission in pair recordings from CA3 pyramidal cells in organotypic culture. J Neurophysiol 81: 2787-2797. Medline

Pavlidis P, Montgomery J, Madison DV (2000) Presynaptic protein kinase activity supports long-term potentiation at synapses between individual hippocampal neurons. J Neurosci 20:4497-4505. Medline

Peça J, Feliciano C, Ting JT, Wang W, Wells MF, Venkatraman TN, Lascola CD, Fu Z, Feng G (2011) Shank3 mutant mice display autistic-like behaviours and striatal dysfunction. Nature 472:437-442. CrossRef Medline

Russo AJ, Devito R (2011) Analysis of copper and zinc plasma concentration and the efficacy of zinc therapy in individuals with Asperger's syndrome, pervasive developmental disorder not otherwise specified (PDD-NOS) and autism. Biomark Insights 6:127-133. CrossRef Medline

Schneider K, Seemann E, Liebmann L, Ahuja R, Koch D, Westermann M, Hübner CA, Kessels MM, Qualmann B (2014) ProSAP1 and membrane nanodomain-associated syndapin I promote postsynapse formation and function. J Cell Biol 205:197-215. CrossRef Medline

Sensi SL, Paoletti P, Koh JY, Aizenman E, Bush AI, Hershfinkel M (2011) The neurophysiology and pathology of brain zinc. J Neurosci 31:1607616085. CrossRef Medline

Shi SH, Hayashi Y, Petralia RS, Zaman SH, Wenthold RJ, Svoboda K, Malinow R (1999) Rapid spine delivery and redistribution of AMPA receptors after synaptic NMDA receptor activation. Science 284:1811-1816. CrossRef Medline

Smart TG, Xie X, Krishek BJ (1994) Modulation of inhibitory and excitatory amino acid receptor ion channels by zinc. Prog Neurobiol 42:393-441. CrossRef Medline

Speed HE, Kouser M, Xuan Z, Reimers JM, Ochoa CF, Gupta N, Liu S, Powell CM (2015) Autism-associated insertion mutation (InsG) of Shank3 exon 21 causes impaired synaptic transmission and behavioral deficits. J Neurosci 35:9648-9665. CrossRef Medline

Takeda A, Fuke S, Ando M, Oku N (2009) Positive modulation of long-term potentiation at hippocampal CA1 synapses by low micromolar concentrations of zinc. Neuroscience 158:585-591. CrossRef Medline

Takeda A, Iwaki H, Ando M, Itagaki K, Suzuki M, Oku N (2010) Zinc differentially acts on components of long-term potentiation at hippocampal CA1 synapses. Brain Res 1323:59-64. CrossRef Medline

Takeda A, Itagaki K, Ando M, Oku N (2012) Involvement of N-methyl-Daspartate receptor subunits in zinc-mediated modification of CA1 longterm potentiation in the developing hippocampus. J Neurosci Res 90 : 551-558. CrossRef Medline

Tsuriel S, Geva R, Zamorano P, Dresbach T, Boeckers T, Gundelfinger ED, Garner CC, Ziv NE (2006) Local sharing as a predominant determinant of synaptic matrix molecular dynamics. PLoS Biol 4:e271. CrossRef Medline

Waites CL, Specht CG, Härtel K, Leal-Ortiz S, Genoux D, Li D, Drisdel RC, Jeyifous O, Cheyne JE, Green WN, Montgomery JM, Garner CC (2009) Synaptic SAP97 isoforms regulate AMPA receptor dynamics and access to presynaptic glutamate. J Neurosci 29:4332-4345. CrossRef Medline

Wang X, McCoy PA, Rodriguiz RM, Pan Y, Je HS, Roberts AC, Kim CJ, Berrios J, Colvin JS, Bousquet-Moore D, Lorenzo I, Wu G, Weinberg RJ, Ehlers MD, Philpot BD, Beaudet AL, Wetsel WC, Jiang YH (2011) Synaptic dysfunction and abnormal behaviors in mice lacking major isoforms of Shank3. Hum Mol Genet 20:3093-3108. CrossRef Medline

Watt NT, Griffiths HH, Hooper NM (2013) Neuronal zinc regulation and the prion protein. Prion 7:203-208. CrossRef Medline

Westbrook GL, Mayer ML (1987) Micromolar concentrations of Zn2+ antagonize NMDA and GABA responses of hippocampal neurons. Nature 328:640-643. CrossRef Medline

Wigström H, Gustafsson B (1986) Postsynaptic control of hippocampal long-term potentation. J Physiol 81:228-236. Medline

Yasuda H, Yoshida K, Yasuda Y, Tsutsui T (2011) Infantile zinc deficiency: association with autism spectrum disorders. Sci Rep 1:129. CrossRef Medline

Zheng N, Jeyifous O, Munro C, Montgomery JM, Green WN (2015) Synaptic activity regulates AMPA receptor trafficking through different recycling pathways. Elife 4. CrossRef Medline 